\title{
THE RISE OF EXCLUSIVE BOARDING HOUSES: Gentrifying Kampung Through New Wave of Urbanization in Jakarta
}

\author{
Dwiyanti Kusumaningrum ${ }^{\mathrm{I}^{*}}$, Jalu Lintang Yogiswara Anuraga ${ }^{2}$, Tria Anggita Hafsari \\ ${ }^{I}$ Research Center for Population Studies, Indonesian Institute of Sciences (LIPI) \\ ${ }^{2}$ Research Center for Society and Culture, Indonesian Institute of Sciences (LIPI) \\ *Corresponding author email: dwiyanti.kusumaningrum@gmail.com
}

\begin{abstract}
This study discusses gentrification in Kampung Paseban caused by the urbanization of Jakarta. The aim of this study is to show how urban processes create gentrification in kampung, focusing on the rise of exclusive boarding houses and its consequence on social changes within Kampung Paseban in Central Jakarta. The analysis employs a qualitative approach that emphasizes the interpretation of the spatial and urban social changes in Kampung Paseban. The method consists of literature review, spatial mapping, in-depth interviews, and field observations. This study shows that the rise of exclusive boarding houses followed by the influx of middle-class migrants has created dualism in both the physical and social aspects of the kampung. The old kampung vibe in Kampung Paseban has now diminished and has been replaced by the emergence of exclusive boarding houses which has become ubiquitous since the 2000's. Gentrification has created a competitive environment in the local economy which causes struggles for the natives and the settlers. In terms of sociocultural impact, the existence of exclusive boarding houses that provide a more private space and are disconnected from the surrounding environment causes social interaction to become more less between the newcomers and the natives. This study shows how kampung copes with urban situations; creating a new social environment, which demonstrates urbanism within kampung.
\end{abstract}

Keywords. gentrification, exclusive boarding houses, Jakarta, kampung, social change

\section{Abstrak}

Penelitian ini membahas gentrifikasi yang terjadi di Kampung Paseban akibat urbanisasi Jakarta. Tujuan dari penelitian ini ingin melihat bagaimana urbanisasi menciptakan gentrifikasi dalam kampung, yang berfokus pada munculnya kos eksklusif dan konsekuensinya pada perubahan sosial di Kampung Paseban, Jakarta Pusat. Analisis menggunakan pendekatan kualitatif yang menekankan pada interpretasi perubahan spasial dan sosial di Kampung Paseban. Metode penelitian terdiri dari tinjauan pustaka, pemetaan spasial, wawancara mendalam, dan observasi lapangan. Studi ini menunjukkan bahwa maraknya kos eksklusif yang diikuti dengan masuknya pendatang kelas menengah telah menciptakan dualisme dalam kampung, baik secara fisik maupun sosial. Suasana kampung lama di Kampung Paseban kini sudah surut dan tergantikan dengan munculnya kos eksklusif yang sudah ada di manamana sejak tahun 2000-an. Gentrifikasi telah menciptakan lingkungan yang kompetitif dalam ekonomi lokal yang menyebabkan penduduk asli dan pemukim harus berjuang untuk bertahan hidup. Dari sisi dampak sosial budaya, keberadaan kos eksklusif yang menawarkan privasi dan terputus dari lingkungan sekitar menyebabkan interaksi sosial antara pendatang dan penduduk asli semakin berkurang. Studi ini menunjukkan bagaimana kampung menghadapi situasi perkotaan; menciptakan lingkungan sosial baru, yang menunjukkan urbanisme di dalam kampung.

Kata kunci: gentrifikasi, Jakarta, kampung, kost eksklusif, perubahan sosial 


\section{INTRODUCTION}

Gentrification has become a global phenomenon. It has diffused geographically and more diverse than the early gentrifications in Europe and North America (Smith, 2002). The global spread of gentrifications has been understood as an important part of 'neo-liberalism' where global 'forces' drive urbanization in cities around the world (Harris, 2008). This global 'forces' or the capital accumulation take urbanization as the new form supplanting industrialization in the past (Lefebvre, 2005). Neil Smith (2008) stated that gentrification is part of this process and is "happening on a more massive scale in Shanghai and Mumbai,..than in the older postindustrializing cities of Europe, North America and Oceania".

The discourse on gentrification has been evolved since the introduction of its classic version by Ruth Glass (1964) in London. Neil Smith (2000) defined it as "reinvestment of capital at the urban center, which is designed to produce space for a more affluent class of people than currently occupies that space". Thus, gentrification is not merely about the replacement of working-class people by the "gentry" or the middle class, but it is beyond that process, that is the capital accumulation. Moreover, a study on gentrification in Scotland stated that the processes are characterized by 'accumulation by dispossession' (Sutherland, 2018). This leads to displacement of existing residents, through a variety of mechanisms, such as rent increases, property taxes, and rising land values (Lees, Slater, Wyly, Slater, \& Wyly, 2013). In many cases, most of the gentrification processes lead to social upgrading of the local, changing the landscape, and displacing the residents.

The studies of global gentrification have been focused on North American and European cities and have yet to involve cities from the global 'South' (Harris, 2008). In Asia, gentrification has been studied in Japan, South Korea, China, India, and Singapore (Arkaraprasertkul, 2018; Harris, 2008; Moore, 2013). However, only a few are accounted in Southeast Asian countries.
In Indonesia, gentrification is part of the urbanization process which has been triggered by the economic liberalization policy in the New Order era ${ }^{\mathrm{I}}$. To restore macro-economic stability, the Indonesian government implemented fiscal policy by issuing a number of policy packages that encouraged the private sector to play a greater role in the country's urban development (Bank Indonesia, I997; Kenichiro, 2015b). One of the most significant moves was the October 1988 Policy Package (or Pakto 88), it was a deregulation that facilitated private sectors in the establishment of new banks (Bank Indonesia, I997). The property sector began to grow rapidly along with the Pakto 88 (Kusumaningrum, 20I8). Thus, the urban development especially Jakarta as the capital city has been affected by the global economic and political situation.

In Jakarta, gentrification has been linked with the property boom seen by the emergence of CBDs (Central Business Districts), real estates, superblocks, office towers, hotels, etc. The main streets of Jakarta are now full of tall buildings cascading the kampung, the old neighborhoods, on their behinds.

In Central Jakarta, Kampung Paseban has experienced gentrification for the last two decades. The main streets in the kampung are now full of office buildings, cafés, apartments, and exclusive boarding houses. Kampung Paseban which is one of the oldest native Betawi kampung has been gradually inhabited by middle-class migrants from various regions.

Based on those facts, it is important to understand how urbanization in Jakarta creates gentrification as it seen through construction boom in the kampung. Therefore, this paper aims to deliver in-depth empirical analysis which shows the gentrification process in Jakarta, focusing on the rise of exclusive boarding houses which brings economic and sociocultural impact to the natives in Kampung Paseban, one of the oldest neighborhoods in Central Jakarta.

I It was due to decline in world oil prices in 1983 and 1986 which affected macroeconomic stability 
Moreover, it is important to know what extent gentrification impacts the social life within kampung. To understand those phenomena, this paper aims to focus on analyzing both the physical changes and urban social changes that occurred in Kampung Paseban.

The methods for this research employ a qualitative approach that emphasizes the interpretation of the spatial and urban social change in Kampung Paseban, Central Jakarta. In-depth interviews were conducted to gather information about the land use changes including the development of exclusive boarding houses and small businesses in the study area, the kampung livelihoods, as well as the social interaction between kampung residents. The researchers conducted interviews with long-term residents, former kost occupants, kost/kontrakan owners, and business players in Kampung Paseban. Furthermore, field observations were conducted to capture the existing landscape of the kampung.

The researchers analyzed how the gentrification in Paseban influenced urban social changes among the kampung residents. The urban social changes were analyzed from the demographic changes, sociocultural aspects of and the local economy of Kampung Paseban. Moreover, this study aims to deliver a new narrative of gentrification in Jakarta and demonstrate urbanism within kampung which demands more attention within contemporary urban discourse.

\section{KAMPUNG PASEBAN AND URBANIZATION IN JAKARTA}

Massive urbanization in Jakarta has caused kampung $^{2}$ to become an enclave in the middle of urban concrete jungles. According to Firman Lubis (2018) Paseban was one of the settlements that developed rapidly in the I96os. Consequently, Kampung Paseban has been struggling with urbanization in their neighborhoods.

$2 \quad$ As an organic settlement, kampung in old Jakarta are essentially rural, where almost every household owns agricultural land and cultivate their land (See Cybriwsky \& Ford, 2001).
"The kampung is central and yet peripheral at the same time. It is simultaneously in and out of place. It is geographically in the "middle" of the city, yet it is seen and unseen at the same time" (Abidin Kusno, 2019)

Kampung represents rural characteristics as well as urbanism at the same time. This is also the characteristics of Kampung Paseban. As Jakarta developed, kampung has been gradually transformed into urban settlement, forcing the people to adapt with the urban situations in their surroundings. This phenomenon has occurred especially in the center of Jakarta, where most organic kampung are urbanized. Thus, several studies have used the term urban kampung to distinguish kampung as a village located in rural area with those that stand on the highly-densed urban neighborhoods located in the city (see Haryadi, I989; Newberry, 2008; Puspitasari, Djunaedi, \& Putra, 2012). However in this paper, the researchers still use the term kampung instead of urban kampung with the assumption that the reader already understands this term in accordance with the Jakarta context.

Previous studies showed that massive urbanization in Jakarta had caused kampung to become shelters for migrants from rural areas (see Jellinek, I994; Murray, I994; van Voorst, 2018). Huge expectations of a better living in the city have caused rural people with all their limited skills and money gathered in the kampung to try their luck and harness their hopes in the city. As a result, kampung, especially those which are in the near urban center, has become increasingly crowded.

Kampung Paseban which was previously known as the native Betawi settlement has been inhabited by migrants from various regions. Based on our interview, there are Sundanese, Javanese, Medan, Padang, East Timor, Papuans, and other ethnic backgrounds within the kampung. Since the ig6os, the ethnic composition of Jakarta's population has increased due to the rapid urbanization process; most of the migrants came from various regions on the island of Java and outside Java (Lubis, 20I8). Therefore, Jakarta has always been known as the melting pot of various ethnic groups in Indonesia (Blackburn, 20II; Lubis, 20I8; Suswandari, 20I7). 
Unlike in the colonial era, where kampung in Jakarta were segregated based on ethnic backgrounds ${ }^{3}$, kampung now tend to be heterogeneous due to the rapid assimilation under high-density living conditions; and this is similar to what happens in Paseban. A single kampung in Jakarta, like Paseban, can also be a melting pot because various ethnic groups are now living in a smaller spatial entity called kampung.

Located in Salemba, near big universities ${ }^{4}$, hospitals, shopping mall and other business areas, Kampung Paseban has been gradually inhabited not only by the 'rural migrants' but also middle-class migrants, consist of students and professional workers from various regions. Unlike in the past where migrants were mostly rural people (who then considered as unskilled and semi-skilled workers in Jakarta), the migrants nowadays tend to be well educated and have a higher degree of adaptation to urban culture.

\section{DEMOGRAPHIC CHANGES}

During the period I980-I990, it was indicated that there was rapid spill-over of population to the outskirts of Jakarta. The urban population growth in Botabek ${ }^{5}$ region was considerably higher than Jakarta (Firman \& Dharmapatni, I994). The study of Jabodetabek Metropolitan Development Plan Review found that during the late I980s, there was about 200,000 out-migration from DKI Jakarta per year (see Firman \& Dharmapatni, I994). This process had an impact on the demographics of Jakarta, particularly in the central area of Jakarta including Kampung Paseban.

The population of Kampung Paseban has decreased significantly during the period I980-2000 (Figure I). This indicates that the

3 The kampung in Jakarta were segregated because it was frequently identified according to the ethnic background of the residents, for example Kampung Bali, Kampung Ambon, and Kampung Makassar (Krausse, 1982).

4 One of the universities is University of Indonesia, which was previously known as STOVIA, the oldest college in Batavia.

5 Botabek is the abbreviation of Bogor, Tangerang, Bekasi.

\section{Demographic profile of Paseban}

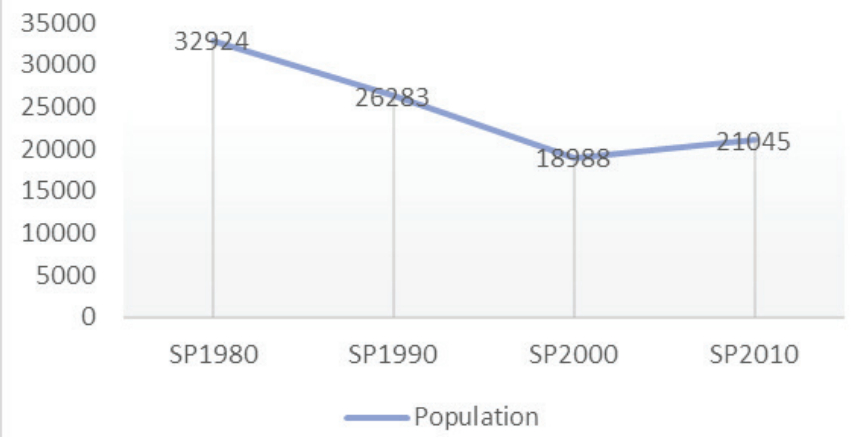

Figure I. Number of populations in Kampung Paseban based on Population Census

population growth rate of Kampung Paseban was declined, indicating that there is a decline in the rate within period I980-I990 (-2.23) and I990-2000 (-3.2). Within that period, many old residents migrated outside Jakarta. The next decade, there was an increase in the rate of population growth in Kampung Paseban. It indicated that there has been in-migration to the kampung during the last decade.

Kampung Paseban has become a densely populated kampung in Jakarta and has a small number of open spaces (Sujatini, Soemardi, Alamsyah, \& Darmajanti, 2015). The population density in Kampung Paseban is 4I075 inhabitants $/ \mathrm{km}^{2}$ (Badan Pusat Statistik, 20I8). According to the statistic report, it is recorded that up to 598 migrants arrived in Paseban in 20I7. The dense population demands adequate housing to accommodate migrants who decide to live in Kampung Paseban.

\section{THE RISE OF EXCLUSIVE BOARDING HOUSES IN PASEBAN}

Over the past few decades, Paseban has been gentrified during Jakarta's rapid development, seen from the emergence of offices, restaurants, cafés, hotels, apartments, and exclusive boarding houses. Many people in Paseban own a boarding house and rent their properties in a form of individual rooms. This kind of business has been such a trend for the natives in terms 
of generating their either main or additional income.

Some of the residents whom the researchers interviewed told that their neighbors had sold their "rumah lama" (old houses) to the investors/gentrifiers. Many gentrifiers are rich Chinese people who have higher financial capital than the natives. The natives mostly moved to the Jakarta suburbs. Some of the residents (which have enough financial capital) had adapted their houses to meet the needs of middle-class migrants, by creating rooms for rent. However, it should be noted that not every people have enough financial capital to improve their houses. Various gentrifiers (based on their financial capital) have indirectly created various types of boarding houses in Paseban.

Thus, the researchers categorized house accommodations in Kampung Paseban into three types: (I) regular boarding houses (kos biasa), (2) rented houses (kontrakan), and (3) exclusive boarding houses (kos ekslusif). A regular boarding house mostly located in the kampung alleys and basically an ordinary house that has a simple terrace and a common space-living room and a kitchen. It usually has no more than 2 floors and is located on the same roof with the landlord's house.

Meanwhile kontrakan is a single house or split house which is usually rented to a single family. Based on the interviews with one of the kontrakan owners, kontrakan tenants are often their own relatives who come to Jakarta and do not have permanent residences. The last, is an exclusive boarding house. The exclusive boarding house is mostly located in the main road of the kampung and has more than 2 floors. In this type of accommodation, car parking facilities is a mandatory service that they should provide. It is because most of the tenants are middle class people who own not only motorcycles but also cars. The emergence of kost exclusive which has become ubiquitous since the 200o's has replaced the old kampung vibe in Kampung Paseban.

There are 75 exclusive boarding houses spread across the eight RW (Community Unit) in Paseban. The exclusive boarding houses are
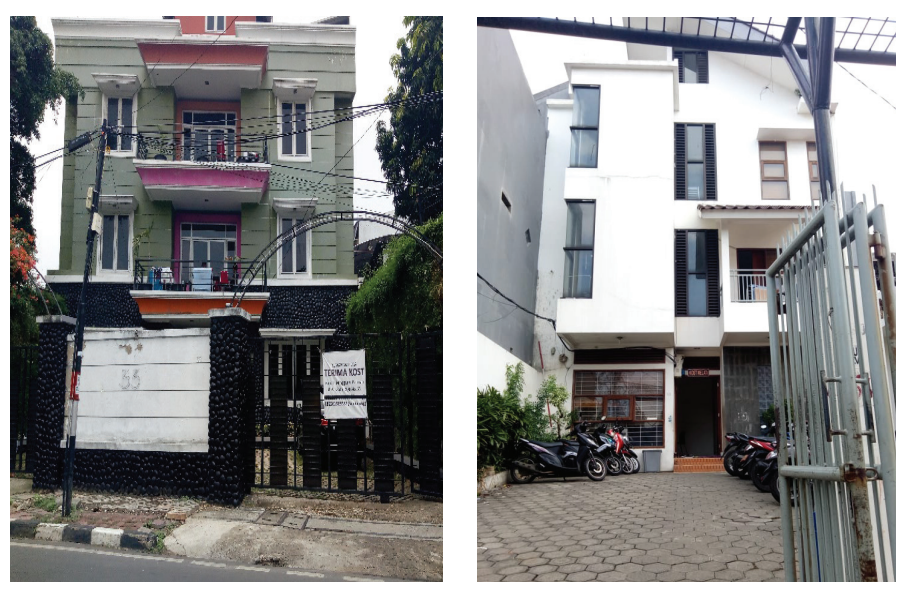

Figure 2. Exclusive boarding houses in the kampung

mostly located along the main roads. Beside the exclusive boarding houses, in the western part of Paseban, there is Salemba Residence, twotower apartments which has been established since 20I0. Each tower has 29 floors and there are approximately 718 units. Furthermore, there are some houses along the main road which have been converted to small hotels namely Hotel Salemba Indah, Hotel Caristo Grande, and Hotel Maxone.

Based on the observations, the spatial pattern of the buildings in the kampung is quite similar with the spatial pattern in the past, where exclusive boarding houses (rumah gedong

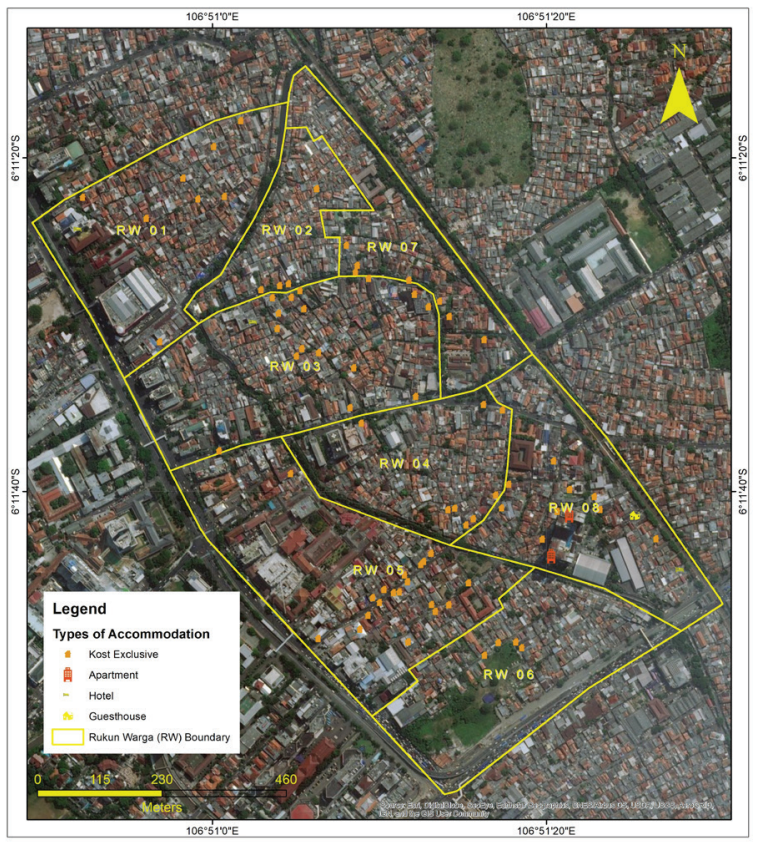

Figure 3. Spatial distributions of exclusive boarding houses 
in the past) are located in the main roads and the small ones are located inside the kampung, behind those rumah gedong ${ }^{6}$. It is interesting that the old pattern can still be found nowadays despite massive urban development continues to take place in Jakarta.

\section{IMPLICATIONS ON SOCIOCULTURAL ASPECT}

The rise of exclusive boarding houses followed by the influx of middle-class migrants has caused the composition of the Paseban population to become increasingly diverse, especially in terms of ethnicity and social status. This may lead to the construction of identity in Paseban.

In this research, the researchers define three identities of the residents: the natives, the settlers, and the newcomers. These three categories are classified based on the birthplace and the longevity of the residence. The first category is the natives, these people are Betawi and a city born people, or the people who were born in Jakarta. The second category is the settlers, these people are migrants from various regions who have lived in Jakarta for a long time (they have $2^{\text {nd }}$ generation in Jakarta). They also often identify themselves as orang Jakarta even though they have various ethnic backgrounds. The last category is the newcomers, or migrants from various regions who recently lived in Paseban.

The strengthening identity of the three groups arises because of the need for identity. Identity plays a role in the formation of a sense of belonging. Sense of belonging is important considering that humans are social creatures. The natives need that sense of belonging when they start to feel marginalized by the newcomers.

The natives, especially the Betawi, have been increasingly marginalized due to the influx of the newcomers. The Betawi have been deprived of the roots of their cultural life caused not only from migration, but also the capital accumulation process which affects their identity and existences in the kampung. Gentrification

6 This kind of pattern were also similar with the tipology of kampung found in Yogyakarta (Guinness, 1986) in Paseban made them compete with new strategies; they can no longer preserve their land as their assets but as production capital."

The decrease of Betawi in the kampung which is often followed by transfers of land ownership has created the impression that they are alienated from their homeland. This is the same as what Fukuyama expressed:

"The psychological dislocation engendered by the transition from Gemeinschaft to Gesellschaft laid the basis for an ideology of nationalism based on an intense nostalgia for an imagined past of strong community in which the divisions and confusions of a pluralist modern society did not exist." (Francis Fukuyama, 2020)

Land becomes important for people's identity. For the Betawi people, the more they sell their land to the migrants, their existence become weaker in the kampung. Many outsiders, even those who originally rented Betawi houses, have bought those houses and become owners. The Betawi people themselves are increasingly marginalized. Even Betawi people cynical expressions appear, such as "don't give outsiders a place, if once given a place, it's hard to move them out". They often call it nyarang. Etymologically, 'nyarang' means make a nest, but Betawi people use it metaphorically which means outsiders occupy the kampung for a long time. This expression clearly expresses their concern for newcomers and their potential to occupy the living space of the Betawi people.

This is exacerbated by the melting process that is becoming increasingly rare. For decades, the Betawi people as indigenous people have a power relation as landlords. This position provides legitimacy for Betawi to control community values. The migrants as tenants must adapt to local values and norms. On the contrary, the exclusive boarding houses, which in fact belong to outsiders, also cause the loss of the acculturation function within kampung.

In Durkheim's perspectives, the shift in social ties is also evident from mechanical to organic solidarity (Ritzer \& Goodman, 2004). This organic bond ultimately rests on a mutually beneficial division of labor, not like a mechanical bond which is based on shared norms. The loss of this mechanical bond within the natives also 
poses a threat to them who are used to relying on a sense of belonging. With the demands of relationships based on mutual benefit, many social ties were cut off. Evenmore, this threatens the position of the natives. Those who have thus far adapted to the same culture as the Betawi culture are forced to be confronted with an order that increasingly presses their group.

On the other hand, the settlers feel that they do not have strong ties to their homeland and do not have ethnic similarities with the Betawi people. This ambiguity has created mutuality of being between them, therefore the identity of this group has emerged. This is similar with Jellinek (I994) which stated that social ties in kampung are formed under high-density living conditions and the common social class and origins. The longevity of residence is also an important feature that encourage strong social ties (Morris, 2019).

The settlers used to live with the Betawi people in one house or one yard. Most of them are of the lower working class whose lives still depend a lot on social ties. These two factors form an interaction that is more accommodating for an assimilation of society. As for migrants whose economic conditions are quite good, they usually open a small business, such as a grocery store, and live in that house too. This form of business clearly requires a good network with the surrounding community to secure the market target. In short, the settlers model requires more integration with the surrounding community to secure their daily life.

However, since gentrification happened in the kampung, they were squeezed into a situation of conflict between the newcomers and the natives. The settlers' identity becomes strategic for them; the generations who have been born in the kampung and feel they are part of the peers. Meanwhile, the newcomers are bound by a sense of belonging in Jakarta when they do not have relatives in the city where they have migrated.

This has become increasingly clear in the last decades when gentrification has played a major role in changing social ties between the people in the kampung. The existence of exclusive boarding houses that provides a more private space and are disconnected from the surrounding environment causes social interaction to become more less between the newcomers and the natives. This is different from the past where ordinary boarding houses and kontrakan formed strong social bonds between owners and tenants.

This shift in the social context becomes increasingly vulnerable if the level of welfare is getting more unequal. The feeling of nostalgia for glory mentioned by Fukuyama above can encourage certain groups to become chauvinists and see other groups as competitors. This is part of Jakarta's gentrification that should be anticipated when many natives have been displaced or have moved to neighborhoods further away from the city. Meanwhile, the current urban environment tends to be occupied by the newcomers.

\section{GENTRIFICATION IMPACT ON KAMPUNG'S LOCAL ECONOMY}

In the context of the local economy, the emergence of gentrification is believed to create new jobs (Byrne, 2003). Strategic areas along main roads tend to attract investors to gentrify those areas into commercial areas (Freeman, 2005). However, this "upgrading" process in fact affects the former residents due to the rising property prices. Residents who cannot afford high property prices are vulnerable to displacement, being forced to move out from the kampung. This also happened in Paseban. Many old residents including the Betawi who had lived in Paseban moved out and dispersed over the southern part of Jakarta suburbs such as Cilandak, Cijantung and Depok because of this process.

In addition to that, gentrification in Paseban could not create job opportunities for the residents. Based on the field observations, the informants (who work as minimarket cashiers and baristas at cafes in Paseban) are non-residents or outsiders. Commercial business which is believed to create job opportunities did not involve the residents of Paseban. 
The findings are three identities as an implication of gentrifying in Paseban: native, settlers, and newcomers. These identities also can describe how their lifestyle and economic background. In general, natives and settlers tend to adhere to conventional lifestyles such as interaction with neighbors, shopping at food stalls, and chatting at gardu (guard post) or warkop (traditional coffee shop) . In short, native and settlers are used to live a life without any intervention of modernization (e.g the use of smartphones). Social interaction between peers is something important to be preserved through their daily lives because that is how they used to be. Demand of need each other is higher than they need technology. Quoting Amiruddin (20I0) that traditional society has high social solidarity.

In contrast to the newcomers, most of the millennial generation, who are amused by urban lifestyle nowadays somewhat depends on technology such as shopping at convenience stores, buying food using delivery applications, and drinking coffee that made by coffee machines. Newcomers tend to be individualistic because many exclusive boarding houses provide facilities with easy access. Hence, they do not need much interaction with other residents. The ability of the newcomers to access facilities, especially those provided by the exclusive boarding house, cannot be separated from their economic background. Furthermore, the increasing number of exclusive boarding houses will also increase newcomers with a high economic background. The impact is that the standard of living in Paseban can increase even though not all residents in Paseban are able to keep up with the economic dynamics that occur. This phenomenon creates a dichotomy in economic patterns that is reflected in their economic background and lifestyle.

Based on this description, gentrification in Paseban formed two economic patterns; urban and traditional economic pattern, First, the urban economic pattern formed by the existence of the exclusive boarding houses (the newcomers) and the second, the traditional economic pattern which has become part of the natives and the settlers' lives. Thus, gentrification indirectly caused kampung as contested space between the two economic patterns. This also raises the question: which economic patterns will last? Is the traditional economic pattern able to survive amidst the rapid urbanization?

Berrey (2005) and Lyons (1996) in Prayoga (2013) stated that gentrification has positive and negative impacts. The gentrification impact is considered positive if residents could get the benefits in the gentrified region. Meanwhile the negative if there are losses that occur due to the process of gentrification (Prayoga \& Esariti, 2013). Regarding the gentrification impact on the local economy in Paseban, this depends on the resident's mindset about the capitalism's logics of action.

Opportunism as one of capitalism's logics of action is one of the factors that influence the dynamics of the local economy of the residents. To survive, many residents see the gentrification as an economic opportunity amid the rapid urban changes within their neighborhoods. Even though there are many minimarkets, café, and other modern kinds of commercial business, the residents have still opened their warung/ food stalls, warung kopi/traditional coffee shop (warkop), etc. Besides, the residents have also coped with the development by opening other small businesses such as laundry cleaning, small grocery shops, and stationery shops to provide the newcomers or their market target. These coexistences, warung vs minimarket, café vs warkop, prove what Kusno (2019) wrote on Provisional notes on semi-urbanism; kampung represents rural characteristics as well as urbanism, where the kampung and urban life coexists.

Warung (stalls) / warung nasi (food stalls), coffee shops / traditional coffee shops (warkop), etc., still exist amidst the rise of investors creating the urban scene within kampung. It is because those places are the only public spaces for the natives and the settlers to interact with each other. This public space has been created since a long time ago, so they prefer to stay on the familiarity of their peers. Apart from not being accustomed to the current lifestyle, another reason is because they are economically 


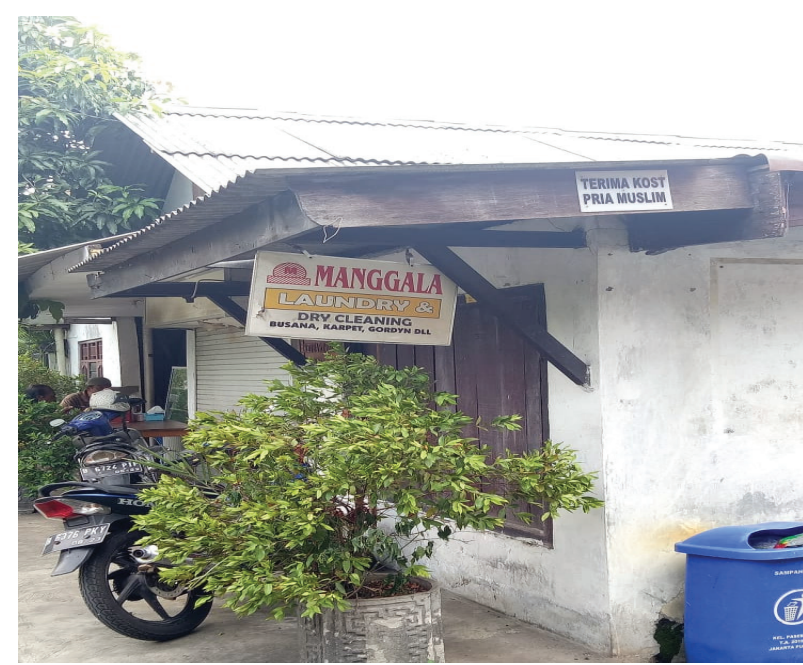

Figure 7. Laundry, one of small business in Kampung Paseban

unable to catch up with the urban style that newcomers tend to have.

However, not all residents can survive with their small business. Instead of creating economic gain, gentrification makes them endure even harder amid a competitive environment. The stalls that were originally a place for buying daily necessities began to be displaced by the emergence of convenience store retailers such as Indomaret, Alfamart, etc. which offered a more complete range of goods, especially for the newcomers.

Gentrification gradually made Paseban dominated by the middle class, which slowly threatened the existence of the locals. The impact of gentrification on the local economy creates a class order in society, in which there is a class of capital owners and workers. The changing urban landscape and demographic transition in Paseban have created an urbanism within kampung. Paseban residents who tend to be in lower economic class are increasingly alienated from the culture of modern urbanism brought by middle-class migrants.

\section{CONCLUSION}

This study shows that urbanization in Jakarta has created gentrification within Kampung Paseban. Unlike classic gentrification where the state and private developers play a significant role, gentrification in Paseban tends to be more organic, it is where the natives themselves sold their lands/houses to the gentrifiers. This research found that gentrification in Jakarta is similar with the gentrification in Shanghai (see Arkaraprasertkul, 20I8); this support the idea of an alternative form of gentrification, where the existing residents themselves has become key actors for the gentrification process.

The rise of exclusive boarding houses followed by the influx of middle-class migrants has created dualism in both the physical and social aspects of the kampung. The exclusive boarding houses has now become the main commodity in contested space within kampung that affect the natives forced to move to the suburbs or trapped and stranded in the middle of a crowded kampung. Some natives who sold their houses moved out and dispersed over the southern part of Jakarta suburbs such as Cilandak, Cijantung and Depok. Some other natives have remained in the kampung but live in the alleys. Thus, the natives, especially Betawi, have been increasingly marginalized due to the influx of the newcomers.

The kampung is now inhabited not only by the 'rural' but also 'urban' migrants which create demographic diversity within kampung. The demographic changes in Paseban bring economic and sociocultural impact to the natives in the kampung. In terms of economic impact, theoretically gentrification is believed to create new jobs. Yet in fact, gentrification has created a competitive environment in the local economy which creates struggles for the natives and the settlers. In terms of sociocultural impact, the existence of exclusive boarding houses that provide a more private space and are disconnected from the surrounding environment causes social interaction to become more less between the newcomers and the natives. Gentrification gradually made Paseban dominated by the newcomers, which slowly threatened the existence of the locals. This study shows how kampung copes with urban situations; creating a new social environment, which demonstrates urbanism within kampung amid the threats of gentrification. 


\section{REFERENCES}

Arkaraprasertkul, N. (20I8). Gentrification and its contentment: An anthropological perspective on housing, heritage and urban social change in Shanghai. Urban Studies, 55(7), I56I-I578. https://doi.org/Io.II77/0042098016684313

Badan Pusat Statistik. (20I8). Senen in Figures 2018. Jakarta Pusat.

BI. (I997). Sejarah Bank Indonesia: Perbankan Periode 1983-I997. Jakarta.

Blackburn, S. (20II). Jakarta: Sejarah 400 Tahun. Jakarta: Masup Jakarta.

Byrne, J. P. (2003). Two Cheers for Gentrification. Howard Law Journal, 46(3), 405-432.

Cybriwsky, R., \& Ford, L. R. (200I). City profile Jakarta. Cities, I8(3), I99-2Io. https://doi. org/Io.Ioi6/So264-275I(OI)oooo4-X

Firman, T., \& Dharmapatni, I. A. I. (I994). The challenges to sustainable development in Jakarta metropolitan region. Habitat International, I8(3), 79-94. https://doi.org/Io.Ior6/oI973975(94)90006-X

Francis Fukuyama. (2020). Identitas: Tuntutan atas Martabat dan Politik Kebencian. Bentang Pustaka.

Freeman, L. (2005). Displacement or Succession? Residential Mobility in Gentrifying Neighborhoods. Urban Affairs Review, 4(4), 463-49I. https://doi.org/Io.II77/I07808740427334I

Glass, R. (I964). London: aspects of change. London: MacGibbon \& Kee.

Guinness, P. (1986). Harmony and Hierarchy in a Javanese Kampung. Oxford University Press.

Harris, A. (2008). From London to Mumbai and back again: Gentrification and public policy in comparative perspective. Urban Studies, 45(I2), 2407-2428. https://doi. org/I0.II77/0042098008097100

Haryadi. (I989). Resident Strategies for Coping With Environmental Press: Relation to House-Settlement System in a Yogyakarta Kampung, Indonesia. University of Winconsin-Milwaukee.

Jellinek, L. (1994). Seperti Roda Berputar: Perubahan Sosial sebuah Kampung di Jakarta. LP3ES.

Kenichiro, A. (2015). Jakarta "Since Yesterday": The Making of the Post-New Order Regime in an Indonesian Metropolis. Southeast Asian Studies, 4(3), 445-486.

Krausse, G. H. (I982). Themes in Poverty: Economics, Education, Amenities, and Social Functions in Jakarta's Kampungs. Southeast Asian Journal of Social Science, Io(2).
Kusno, A. (2019). Provisional notes on semiurbanism. In R. Padawangi (Ed.), Routledge Handbook of Urbanization in Southeast Asia (pp. 75-89). Oxon: Routledge.

Kusumaningrum, D. (2018). Urban Kampung vs New Town: Spatial Contestation in Jakarta Suburbs, A Case Study in Karawaci-Serpong Area, Tangerang. In ICSSH 20I8-The Role of Social Sciences and Humanities to Strengthen Community Resilience witin Global Nexus (pp. II3-I30). Jakarta: Indonesian Institute of Sciences.

Lees, L., Slater, T., Wyly, E., Slater, T., \& Wyly, E. (2013). Gentrification. Routledge. https://doi. org/I0.4324/9780203940877

Lefebvre, H. (2005). The urban revolution. Minneapolis: University of Minnesota Press.

Lubis, F. (2018). Jakarta I950-I970 (Edisi Komp). Depok: Masup Jakarta.

Moore, R. (2013). Understanding ' Gentrification ' in Southeast and East Asia, I3(I964), II6-I27.

Morris, A. (2019). Gentrification and Displacement: The Forced Relocation of Public Housing Tenants in Inner-Sidney. Singapore: Springer.

Murray, A. J. (I994). Pedagang Jalanan dan Pelacur Jakarta: sebuah kajian antropologi sosial. Jakarta: $\mathrm{LP}_{3} \mathrm{ES}$.

Newberry, J. (2008). Double spaced: Abstract labour in urban kampung. Anthropologica, 50(2), 24I-253. https://doi.org/Io.2307/256054I8

Prayoga, I. N. T. (2013). Keberlangsungan Menetap Penduduk Asli pada Kawasan di Sekitar Kampus UNDIP Tembalang sebagai Permukiman Kota Semarang yang Tergentrifikasi, 9(I), I-IO.

Prayoga, I. N. T., \& Esariti, L. (2013). The Identification of Early Gentrification in Tembalang Area, Semarang, Indonesia. https://doi. org/Io.II77/II033088I3478606

Puspitasari, P., Djunaedi, S. A., \& Putra, H. S. A. (20I2). Ritual and Space Structure: Pilgrimage and Space Use in Historical Urban Kampung Context of Luar Batang (Jakarta, Indonesia). Procedia - Social and Behavioral Sciences, 36(June 20II), 350-36o. https://doi. org/Io.IoI6/j.sbspro.2012.03.039

R. J. Johnston, Gregory, D., Pratt, G., \& Watts, M. (2000). The Dictionary of Human Geography 4th ed. Oxford-Blackwell.

Ritzer, G., \& Goodman, D. J. (2004). Modern Sociological Theory. McGraw-Hill Book Company United States of America.

Smith, N. (2002). New globalism, new urbanism. Antipode, (34(3)), 427-450. 
Smith, N. (2008). On " The Eviction of Critical Perspectives .' International Journal of Urban and Regional Research,32(March), I95-I97. https:// doi.org/Io.IIII/j.I468-2427.2008.00773.X

Sujatini, S., Soemardi, T. P., Alamsyah, A. T., \& Darmajanti, L. (2015). Observation of Public Open Space Utilization for Community in Jakarta , Indonesia, 9(December), 495-500.

Suswandari. (20I7). Kearifan Lokal Etnik Betawi: Mapping Sosio-kultural Masyarakat Asli Jakarta. (Suwarno, Ed.). Yogyakarta: Pustaka Pelajar.
Sutherland, L. (2018). Agriculture and inequalities: Gentrification in a Scottish parish, (December 20I7). https://doi.org/Io.IoI6/j. jrurstud.2018.09.009

van Voorst, R. (2018). Tempat Terbaik di Dunia: Pengalaman Seorang Antropolog Tinggal di Kawasan Kumuh Jakarta. Marjin Kiri. 
